\title{
A plague on both your houses: European and Asian responses to Coronavirus
}

\section{Mark Beeson ${ }^{1}$}

Published online: 18 May 2020

(C) Springer-Verlag GmbH Germany, part of Springer Nature 2020

Students of comparative politics may be the only people who have actually derived some benefit from Coronavirus or COVID-19. Without wanting to trivialise the pandemic's impact, it has provided a searching examination of different countries' capacity to respond to sudden, unprecedented, if not entirely unforeseen crises. Indeed, the first point to make about the way various states responded to the crisis is that those countries that have experienced similar problems in the past have been-unsurprisingly, perhaps-better prepared for this one. It is surely no coincidence that Singapore, for example, which was especially hard hit be the SARS epidemic, responded rapidly and effectively to the impact of COVID-19 (Heijmans 2020).

There are, however, other more enduring determinants of national responses that highlight deep-seated and enduring political and even cultural differences. This brief paper considers the possible origins and significance of such differences at both the national and regional levels. The principal, possibly unsurprising, claim I make is that national responses (and the factors that determine them) remain more important than regional ones. If correct, this suggests that East Asian-style approaches to political order may prove to be increasingly influential, especially if the crisis continues to undermine the European Union's (EU) already precarious sense of solidarity (Krastev and Holmes 2019).

\section{Pandemics are what states make of them}

There is a good deal of debate, some of it paranoid, racist and conspiratorial, about the origins of what is now a pandemic, but one thing seems clear: it began in China. There is a very important general point to be made about human beings' generally negative impact on the natural environment and the threat this may pose to our long-term collective security

Prof. Dr. Mark Beeson is Professor of International Politics at the University of Western Australia.

Mark Beeson

mark.beeson@uwa.edu.au

1 University of Western Australia, Perth, Australia 
(Vidal 2020), but that is not the principal focus of this discussion. What is at issue here is the way different parts of the world and the states within them responded to the challenge posed by COVID-19. In this regard, China has a very mixed report card.

As many critics of China have been keen to point out, the first instinct of the Chinese Communist Party (CCP) was to cover up any news that was likely to reflect badly on its governance of the country and thus its authority, which is ultimately determined by its perceived competence (Kynge et al. 2020). 'Performance legitimacy' may be primarily associated with economic management in authoritarian regimes, but any threat to social order is taken terribly seriously by the CCP, which is why its initial clampdown was so heavy-handed. The instinct to 'shoot the messenger' has proved hard to overcome in a political system that has little tolerance of whistle-blowers or potentially destabilising social activism. And yet, when it became apparent that the threat posed by COVID-19 was so serious and obvious that it could not be concealed, China's authoritarian system rapidly mobilised and imposed draconian, transmission-inhibiting lockdowns in Wuhan and elsewhere (Graham-Harrison and Kuo 2020). Similar restrictions have proved more difficult to impose in other parts of the world.

For some conservative commentators, this is in confirmation of the continuing importance of East Asian cultural values that are not simply different, but in some ways, at least, actually better than those of the individualistic West (Sheridan 2020). Confucian traditions, respect for social hierarchy and a relaxed attitude toward powerful states that 'intervene' in economic and even social affairs, are taken to be indicative of such 'Asian values'. It is striking that, after being widely dismissed in the wake of the Asian financial crisis, such discourses are remerging, and are even promoted by precisely the same people at times (Mahbubani 2020). One of the most important potential consequences of the current crisis is that it will likely intensify the growing competition between 'the West' and other parts of the world, especially regarding the optimal forms of economic and political organization.

Although my focus here is primarily on Europe and Asia, it is not possible to understand the significance of China's response to the crisis without saying something about the notional leader of 'the free world'. Even before this pandemic struck, many had drawn unfavourable comparisons between China and the USA in their responses to, and role in actually creating the so-called 'global financial crisis' of the late $2000 \mathrm{~s}$ (Breslin 2011). The disproportionally negative impact of the current pandemic on the USA, partly as a consequence of its notoriously inequitable and inefficient health system, and partly because of polarised, dysfunctional nature of American politics, has further undermined what remains of its 'soft power'. Much of the blame for the unfolding American tragedy can be attributed to the manifold failings of President Trump (Frum 2020), no doubt, but the absence of leadership on the part of the USA threatens to undermine the foundations of an international order it did so much to create. Significantly, both Western Europe and East Asia are direct products of this order and will be affected profoundly if it unravels.

Space precludes a detailed examination of this legacy and the very different forms of regionalism American hegemony produced (see Beeson 2005), but it is important to recognise that firstly, the regional orders in Europe are different and that secondly, so are the various organisations and intra-regional relationships that exist in both areas. Such differences, and the much greater expectations that Europeans have-or more accurately, perhaps, had - about their leaders to cooperatively respond to such crises, 
make their possible consequences that much greater. The EU was already in trouble before the pandemic hit with such force in Italy, Spain and France, a reality highlighted most dramatically in Britain's populist-inspired decision to leave. Now, there are very real questions being posed about the EU's ability to deal with the immediate health impacts of the crisis, as well as the potentially even more consequential economic effects as countries in Europe's South are plunged into yet another economic emergency (Erlanger 2020).

For better or worse, the same sorts of dynamics are simply not in play to anything like the same extent in East Asia. East Asians have never been enthusiastic about European-style levels of cooperation and political integration, and are fiercely protective of national autonomy and sovereignty. No one in East or Southeast Asia is expecting the Association of Southeast Asian Nations (ASEAN), or any of the other increasing number of overlapping, largely ineffectual regional organizations to oversee a collective response to the crisis (Beeson 2019). On the contrary, populations are looking to national leaders to 'do something', and this is likely throw an unfavourable light on the responses of states such Indonesia and the Philippines in particular, where leaders look out of their depth and state capacities are plainly limited. In some ways, perhaps, the natural environment is revealing not only our continuing vulnerability to crises we find difficult to control, but our responsibility in creating them in the first place.

\section{Pandemics are remaking us}

In this regard, COVID-19 is arguably significant primarily for its breathtakingly rapid spread across parts of the world that hitherto considered themselves immune to such forces. This pandemic like other before it, will eventually pass, however. Yet when compared to the possible impact of unmitigated climate change - which threatens nothing less than the long-term survival of the species in anything approaching a 'civilized' condition at least (McKibben 2019) - COVID-19 may come to be seen as a passing problem. The reason that COVID-19 is triggering such alarm, not to mention unprecedented and hitherto unthinkable policy interventions, is because of the immediacy of the threat it poses. By comparison, climate change is the proverbial but all too real 'slow burner'. The point to make about both threats, however, is that they are having direct and measurable impacts on us and the foundations of the modern industrialised societies than have underpinned unprecedented standards of living and general development. Or they have in some parts of the world, at least.

In this regard, COVID-19 is an equal opportunity enemy. Not even the rich and powerful are immune, although there is no doubt that poorer people and parts of the world will be far more badly affected than their richer counterparts. In this context, at least, some of the more impoverished parts of East Asia may well be hit harder than even places such as Italy and Spain. It is very unlikely that there will be any regional cooperation to share the economic pain caused by the pandemic either. At least the EU is trying to come to the economic rescue; in East Asia there is no similar regional capacity. And yet there is one country that has proved itself capable of making a difference domestically and internationally: China.

China's so-called 'facemask diplomacy' is also generating a good deal of consternation, especially within the security establishment in the USA (Hutt and Crispin 
2020). However, long-term strategic calculations may not be the first priority of recipients of Chinese assistance, which is precisely why they may prove so effective, of course. Given that few parts of Southeast Asia are free of the sort of environmental problems that are implicated in both the current pandemic and the region's long-term bio-security, it is quite possible that China's long-term influence will grow-despite its apparent role in causing the crisis in the first place. In this context at least, realist observers may indeed have some seemingly timeless wisdom to impart: the strong do what they will, and the weak do what they must.

Or they do in East Asia, at least. In Europe, where there is a much greater sense of institutionalised collective fate things are rather different, and the strong have to take notice of the weak; or they do if they want to keep the EU together, at least. One of the great ironies of the current crisis, and one of the potentially fatal flaws that it is exposing in the EU's painstakingly constructed institutional architecture, is that it is hard to maintain unity among members with very different modes of government and economic circumstances (Jenkins 2020). The divisions between the 'frugal four' (Austria, Denmark, Sweden and the Netherlands) and the feckless Southerners have been painfully apparent (Kurz 2020); so, too, has the continuing leverage that the likes of Italy can exert simply because it is too big to fail. The current crisis is providing a stress test like no other, and it is far from clear whether the EU will survive it in anything like its current form at least.

In this sense, the pandemic - and the natural environment more generally, perhapsis beginning to remake international politics in ways we could scarcely imagine only months ago. The frailties of national and international institutions and relationships are being brutally exposed in ways that may permanently transform politics, and the way that we think about particular sorts of individual and collective leadership. Indeed, it is not unthinkable that the very idea of effective international cooperation will experience yet another hammer blow, from which it may not recover.

Hyperbole? I certainly hope so. But at a time when the USA is demonstrating some of the most incompetent leadership domestically and internationally that we have ever seen, and the EU is struggling to articulate, let alone, implement a credible policy agenda around which its disparate parts can unify, then such a claim looks all too plausible. At the very least, China's authoritarian alternative may gain more influence, if not admirers. At the very least, it seems safe to say that the world will never be quite the same again.

\section{References}

Beeson M (2005) Rethinking regionalism: Europe and East Asia in comparative historical perspective. Journal of European Public Policy 12(6):969-985

Beeson M (2019) Asia's competing multilateral initiatives: quality versus quantity. Pac Rev 32(2):245-255

Breslin S (2011) East Asia and the global/transatlantic/Western crisis. Contemp Polit 17(2):109-117

Erlanger S (2020) 'Europe fumbled coronavirus at first. Can it manage the pandemic now? New York Times, March 27

Frum D (2020) This is Trump's fault. The Atlantic, April 7

Graham-Harrison E and Kuo L (2020) China's coronavirus lockdown strategy: brutal but effective. The Guardian 20 March

Heijmans PJ (2020) Singapore contained Coronavirus. Could other countries learn from its approach? Fortune, March 5 
Hutt D and Crispin SW (2020) China steals a Covid-19 march on US in SE Asia. Asia Times, March 26 Jenkins S (2020) The coronavirus crisis has exposed the truth about the EU: it's not a real union. The Guardian 10 April

Krastev I, Holmes S (2019) The light that failed: a reckoning. Allen Lane, London

Kurz S (2020) The "frugal four" advocate a responsible EU budget. Financial times, February 16

Kynge J, Yu S, Hancock T. (2020) Coronavirus: the cost of China's public health cover-up. Financial Times, February 7

Mahbubani K (2020) Has China won? The Chinese challenge to American primacy. Public Affairs, New York

McKibben B (2019) Falter: has the human game begun to play itself out? Wildfire, London

Sheridan G (2020) Coronavirus: the West's civil disobedience — it's a trend to die for. The Australian March 25

Vidal J (2020) "Tip of the iceberg": is our destruction of nature responsible for Covid-19? The Guardian, 18 March

Publisher's note Springer Nature remains neutral with regard to jurisdictional claims in published maps and institutional affiliations. 